\title{
Adventitious roots formation for enhanced and sustainable production of antioxidants in Brassica oleracea var. acephala (Brassicaceae)
}

\author{
M uhammad Adil (iD*1,2, Bilal Haider Abbasi (iD)
}

\author{
${ }^{1}$ H.E.J. Research Institute of Chemistry-Biotechnology Wing, International Center for Chemical and Biological \\ Sciences, University of Karachi, 75270 Pakistan \\ ${ }^{2}$ Department of Biotechnology, Quaid I Azam University Islamabad, 45320 Pakistan
}

\begin{abstract}
Brassica oleracea var. acephala is listed as the healthiest vegetable due to its high valued secondary metabolites content and antioxidant potential. This study was conducted to establish adventitious roots (ARs) culture as an alternative and feasible production of antioxidant secondary metabolites. ARs were induced from cotyledon explants in commercially available Murashige and Skoog (MS) plant nutrient media, gelled with $0.8 \%$ phyto-agar and supplemented with different concentration $(0.1 \quad 1.5 \mathrm{mg} \mathrm{L}-1)$ of auxins ( $\alpha$-Naphthalene acetic acid; NAA, or Indole acetic acid; IAA, or Indole-3-butyric acid; IBA). AR formation responses in MS media at varying concentrations (0 $50 \mathrm{~g} \mathrm{~L}-1)$ of sucrose and initial media $\mathrm{pH}(4,5.0,5.8,7 \& 8)$ were also studied. The bioprocessing of ARs were studied in liquid MS media containing NAA (1.5 mg L-1) as growth regulator. The growth curve, important antioxidants (phenols $\&$ flavonoids), and free radical scavenging potential of ARs were studied for a period of 9-weeks. The ARs at stationary phase (7-week) attained highest accumulation of phenols and flavonoids, which ultimately showed the highest reactive species scavenging potential. This study provides the base for production of B. oleraceae var. acephala secondary metabolites on large scale to strengthen the bio-based economy of developing world.
\end{abstract}

\section{ARTICLE HISTORY}

Received: February 21, 2018

Revised: April 5, 2019

Accepted: May 30, 2019

\section{KEYWORDS}

Adventitious roots,

Phenolics,

Flavonoids,

Antioxidants,

Auxin

\section{INTRODUCTION}

Roots are biosynthetic factories of nutritionally and pharmaceutically important metabolites such as alkaloids, phenols, polyacetylenes, sesquiterpenes and napthoquinones [1]. To render this potential adventious roots (ARs) culture is the promising alternative for large scale production. It is advantageous over cell, microbial and hairy roots cultures as it has fast multiplication rate, resistant to shear-stress, genetically stable, non-GMO, and easily scalable [2]. Unlike opines, toxic chemicals production in hairy roots culture makes it ideal and acceptable to the consumers $[3,4]$.

Brassica oleracea var. acephala belonging to the family Brassicaceae (mustard family) is economically important due to its edibility, fodder and condiment usages and oil content [5, 6]. Traditionally, this plant has been utilized as a vegetable [7, 8], ornamental plant [9] and a

CONTACT: Muhammad Adil $\square$ adilbiotech@gmail.com Ð H.E.J Research Institute of Chemistry, International Center for Chemical and Biological Sciences (ICCBS), University of Karachi, 75270, Pakistan 
medicinal plant. Locally in Kashmir, it is treated as an important foliage herbaceous plant, is used as vegetable and taxonomically it is the oldest form of cabbage [10]. In traditional medicine the intact plant has been reported for blister formation against inflammation and warts [11] and its juices were used to relieve bronchitis, chronic cough and asthma [12]. It has also been utilized for the treatment of cardiovascular diseases and carcinomas of colon, rectum and stomach $[13,14]$. These qualities are linked to its metabolites profile which varies in quality and quantity due to specie type, plant part and age, and other agronomic factors (e.g. environmental and geographic location) [15, 11]. To overcome these constraints; in-vitro cultures have been selected as an attractive, rapid and reproducible method for production of specific metabolites in bulk scale [16].

The multiple utilization practices of this plant have made it ideal for in vitro cultures establishment. In this study, we established adventious root culture system of Brassica oleracea var. acephala and investigated the effects of different auxins, sucrose concentrations, and $\mathrm{pH}$ strength on ARs formation from cotyledon explants. Furthermore, the content of phenolic, flavonoids, and antioxidant potential in the bioprocessed roots were evaluated.

\section{MATERIAL and METHODS}

\subsection{Explant source and adventitious root induction}

The seeds of Brassica oleracea var. acephala were obtained from at Quaid-I-Azam University Islamabad, Pakistan. The surfaces of seeds were sterilized and then inoculated on Murashige and Skoog (1962) solid medium containing $30 \mathrm{~g} \mathrm{~L}^{-1}$ sucrose and $8 \mathrm{~g} \mathrm{~L}^{-1}$ agar [17].

For adventitious root induction, cotyledon and internode explants from 20 days old seed derived plantlet were inoculated on MS media supplemented with various concentrations $(0.1$, $0.5,1.0$ and $1.5 \mathrm{mg} \mathrm{L}^{-1}$ ) of Indole-3-butyric acid (IBA), Indole-3-acetic acid (IAA) and $\alpha$ naphthalene acetic acid (NAA) each. Additionally, the explants were cultured on MS media supplemented with varying sucrose concentrations $\left(0,20,30,40,50,60\right.$ and $\left.70 \mathrm{~g} \mathrm{~L}^{-1}\right)$ and different $\mathrm{pH}$ levels $(4,5.0,5.8,7$ and 8). The data were recorded in terms of percent root induction response, number of roots induced per explant, and roots fresh and dry weight (DW) after 4 weeks of culture.

All cultures were incubated in plant growth room, where room temperature $\left(25 \pm 1^{\circ} \mathrm{C}\right)$ and humidity (70\%) were kept in control. The $\mathrm{pH}$ of culture media was maintained at 5.8 before autoclaving. The $16 \mathrm{~h}$ photoperiod with light intensity of $40 \mu \mathrm{mol} \mathrm{m}^{-2} \mathrm{~s}^{-1}$ was maintained in a growth room.

\subsection{Submerged cultivation of adventitious roots}

The 4-weeks old viable adventitious roots were aseptically excised from leaf explant and inoculated into MS medium, devoid of agar. For roots multiplication medium was supplemented with $1.0 \mathrm{mg} \mathrm{L}^{-1} \mathrm{NAA}$ and $30 \mathrm{~g} \mathrm{~L}^{-1}$ sucrose. To ensure proper aeration, $\sim 0.5 \mathrm{~g}$ ARs were cultured in $250 \mathrm{ml}$ Erlenmeyer (conical) flask. The culture conditions in shaking incubator were set as $24 \mathrm{~h}$ dark, $110 \mathrm{rpm}$ and $25^{\circ} \mathrm{C}$. The adventitious roots from shake flask were sampled after each week of culturing for a total 9-weeks of period, and biomass and secondary metabolites accumulation were measured with the time course.

\subsection{Phytochemical Analysis}

The increase in fresh weight (FW) and dry weight (DW), and residual media electrical conductivity (EC) were measured according to Baque et al [18]. The antioxidants, phenols and flavonoids content in ARs were measured according to Ali \& Abbasi [19], and Tariq et al [20] methods. For antioxidant activity 1-diphenyl-2-picrylhydrazyl (DPPH) was used as free radical producer and its scavenging potential in ARs were measured according to Abbasi et al [21]. 


\subsection{Statistical analysis}

All experiments were carried out in triplicate and were repeated two times. Mean values of the experimented data sets were analysed for variance and significance using Duncan's Multiple Range Test (DMRT) on Statistix (8.1) software. For graphical presentation OriginPro (8.5) was used and error bars represent standard error (SE).

\subsection{Adventitious root induction}

Adventitious root cultures of Brassica oleracea var. acephala were established in four steps i.e. seed germination, aseptic transfer of cotyledon explant to medium, adventitious root induction and submerged cultivation in shake flasks (Fig 1).

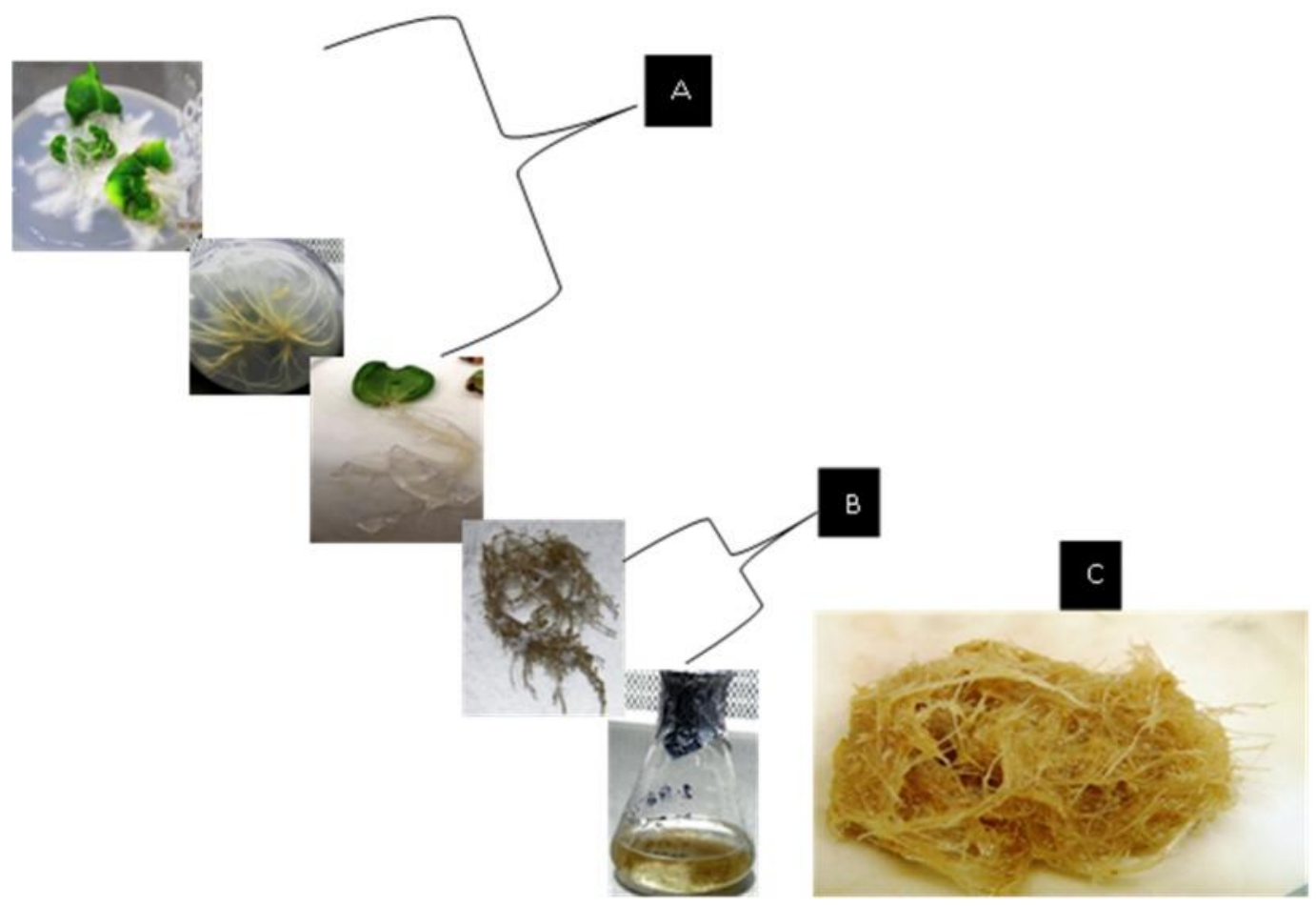

Figure 1. Adventitious root culture establishment A) Induction and elongation of adventitious roots B ) Submerged cultivation, and C) Fresh Biomass.

Cotyledon explants cultured on to MS basal media supplemented with various amounts $\left(0.1,0.5,1.0\right.$ and $\left.1.5 \mathrm{mg} \mathrm{L}^{-1}\right)$ of auxins; NAA, IBA or IAA failed to produce shoots and resulted in induction of the primary adventitious roots at the cut ends in varying frequency (Table 1). However, internode explants induced shorter adventitious roots with maximum frequency (34\%) in response to $1.0 \mathrm{mg} \mathrm{L}^{-1} \mathrm{NAA}$. The cotyledon explants inoculated on MS medium containing $0.5 \mathrm{mg} \mathrm{L}^{-1} \mathrm{NAA}$ resulted into highest adventitious root induction frequency $(87 \%)$ and maximum number of roots per explant (35), fresh weight $(3.0 \mathrm{~g})$ and dry weight $(0.26 \mathrm{~g})$. In response to $1.5 \mathrm{mg} \mathrm{L}^{-1}$ of IAA, maximum (70.7\%) adventitious roots induction was observed. Different concentrations of IBA resulted into significantly lower biomass accumulation and rooting induction frequency. 
Table 1. Auxin type and concentration effect adventitious root formation in cotyledon explant of $B$. oleracea var. acephala.

\begin{tabular}{ccccc}
\hline $\begin{array}{c}\text { Treatment } \\
(\mathrm{mg} \mathrm{l-1})\end{array}$ & $\begin{array}{c}\text { Rooting } \\
\text { frequency }(\%)\end{array}$ & Number of roots & $\begin{array}{c}\text { Fresh Weight } \\
\text { (g/culture) }\end{array}$ & Dry Weight (g/culture) \\
\hline MS $^{0}$ & ND $^{\times}$ & ND & ND & ND \\
NAA 0.1 & $68.7 \pm 2.96 \mathrm{bc} *$ & $14.3 \pm 1.97 \mathrm{c}$ & $1.96 \pm 0.034 \mathrm{c}$ & $0.150 \pm 0.017 \mathrm{abc}$ \\
0.5 & $87.3 \pm 1.45 \mathrm{a}$ & $35.06 \pm 2.31 \mathrm{a}$ & $2.96 \pm 0.035 \mathrm{a}$ & $0.232 \pm 0.088 \mathrm{a}$ \\
1.0 & $79.0 \pm 1.53 \mathrm{ab}$ & $24.33 \pm 2.62 \mathrm{~b}$ & $2.76 \pm 0.038 \mathrm{a}$ & $0.239 \pm 0.007 \mathrm{a}$ \\
1.5 & $76.7 \pm 2.60 \mathrm{ab}$ & $26.90 \pm 1.07 \mathrm{ab}$ & $2.36 \pm 0.037 \mathrm{~b}$ & $0.199 \pm 0.006 \mathrm{ab}$ \\
IAA 0.1 & ND & ND & ND & ND \\
0.5 & $20.7 \pm 2.33 \mathrm{~d}$ & $2.00 \pm 1.15 \mathrm{~d}$ & $1.09 \pm 0.042 \mathrm{~d}$ & $0.088 \pm 0.003 \mathrm{abc}$ \\
1.0 & $32.7 \pm 2.03 \mathrm{~d}$ & $4.53 \pm 1.47 \mathrm{~d}$ & $1.15 \pm 0.052 \mathrm{~d}$ & $0.094 \pm 0.004 \mathrm{bc}$ \\
1.5 & $70.7 \pm 1.76 \mathrm{~b}$ & $7.33 \pm 1.05 \mathrm{~d}$ & $1.29 \pm 0.058 \mathrm{~d}$ & $0.136 \pm 0.011 \mathrm{abc}$ \\
IBA 0.1 & ND & ND & ND & ND \\
0.5 & $27.30 \pm 2.34 \mathrm{~d}$ & $1.60 \pm 0.92 \mathrm{~d}$ & $1.05 \pm 0.028 \mathrm{~d}$ & $0.063 \pm 0.005 \mathrm{bc}$ \\
1.0 & $31.23 \pm 2.69 \mathrm{~d}$ & $1.46 \pm 0.41 \mathrm{~d}$ & $1.053 \pm 0.030 \mathrm{~d}$ & $0.086 \pm 0.008 \mathrm{abc}$ \\
1.5 & $56.50 \pm 2.18 \mathrm{c}$ & $3.59 \pm 1.30 \mathrm{~d}$ & $1.18 \pm 0.056 \mathrm{~d}$ & $0.010 \pm 0.002 \mathrm{bc}$ \\
\hline
\end{tabular}

Data values represent mean \pm SE of three replicates.

$*$ different alphabets in columns notes the significant difference at $\mathrm{P}<0.01$

${ }^{\times} \mathrm{ND}$ : Not Detected

Significant variation in biomass accumulation was observed in response to different concentrations of sucrose while keeping the NAA concentration to $1.0 \mathrm{mg} \mathrm{L}^{-1}$. MS medium supplemented with $40 \mathrm{~g} \mathrm{~L}^{-1}$ sucrose was found to display maximum values for adventitious root induction frequency (86\%), number of roots per explant (16.2) and fresh weight ( $2.3 \mathrm{~g} /$ culture) and dry weight $(0.12 \mathrm{~g} /$ culture $)$ (Table 2$)$. Further increase in sucrose concentration beyond 40 $\mathrm{g} \mathrm{L}^{-1}$ significantly reduced adventitious root induction frequency.

Table 2. The effects of different sucrose concentrations in MS medium on induction of adventitious roots from cotyledon explant.

\begin{tabular}{ccccc}
\hline $\begin{array}{c}\text { Sucrose } \\
\begin{array}{c}\text { concentration } \\
\left.(\mathrm{g} \mathrm{L})^{-1}\right)\end{array}\end{array}$ & $\begin{array}{c}\text { Rooting frequency } \\
(\%)\end{array}$ & Number of roots & Fresh weight (g/culture) & $\begin{array}{c}\text { Dry weight } \\
(\mathrm{g} / \text { culture })\end{array}$ \\
\hline 0 & $\mathrm{ND}$ & $\mathrm{ND}$ & $\mathrm{ND}$ & ND \\
20 & $40.64 \pm 2.4 \mathrm{c}$ & $3.33 \pm 1.3 \mathrm{c}$ & $0.81 \pm 0.1 \mathrm{~b}$ & $0.05 \pm 0.012 \mathrm{a}$ \\
30 & $59.90 \pm 1.3 \mathrm{~b}$ & $7.33 \pm 1.9 \mathrm{bc}$ & $1.73 \pm 0.4 \mathrm{ab}$ & $0.09 \pm 0.023 \mathrm{a}$ \\
40 & $86.67 \pm 1.5 \mathrm{a}$ & $16.30 \pm 1.5 \mathrm{a}$ & $2.29 \pm 0.2 \mathrm{a}$ & $0.12 \pm 0.034 \mathrm{a}$ \\
50 & $77.80 \pm 2.7 \mathrm{a}$ & $10.96 \pm 2.5 \mathrm{ab}$ & $1.42 \pm 0.2 \mathrm{ab}$ & $0.06 \pm 0.025 \mathrm{a}$ \\
60 & $51.15 \pm 2.3 \mathrm{bc}$ & $4.59 \pm 0.9 \mathrm{c}$ & $0.70 \pm 0.3 \mathrm{~b}$ & $0.04 \pm 0.003 \mathrm{a}$ \\
70 & $25.74 \pm 1.9 \mathrm{~d}$ & $2.67 \pm 1.8 \mathrm{c}$ & $0.50 \pm 0.1 \mathrm{~b}$ & $0.03 \pm 0.007 \mathrm{a}$ \\
\hline
\end{tabular}

Data values represent mean \pm SE of triplicates.

*ND; not detected

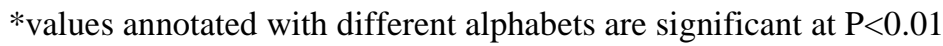

Among different levels of $\mathrm{pH}$ tested, while keeping sucrose $30 \mathrm{gL}^{-1}$ and NAA $0.5 \mathrm{mgL}^{-1}$ constant, highest adventitious root induction frequency (84.6\%) with maximum number of roots per explant (21.04) and fresh weight $(2.5 \mathrm{~g} /$ culture $)$ and $0.24 \mathrm{~g}$ dry weight $(0.24 \mathrm{~g} /$ culture $)$ were recorded in response to $\mathrm{pH}$ 5.8. Significant decrease in adventitious rooting was observed at all other $\mathrm{pH}$ levels compared to 5.8 (Table 3 ). 
Table 3. The effects of hydrogen ion concentration $(\mathrm{pH})$ on formation of adventitious roots from cotyledon explant.

\begin{tabular}{ccccc}
\hline $\begin{array}{c}\text { Hydrogen ion } \\
\text { concentration }(\mathrm{pH})\end{array}$ & $\begin{array}{c}\text { Rooting Frequency } \\
(\%)\end{array}$ & $\begin{array}{c}\text { Number of } \\
\text { Roots }\end{array}$ & $\begin{array}{c}\text { Fresh Weight } \\
(\mathrm{g} / \text { culture })\end{array}$ & $\begin{array}{c}\text { Dry Weight } \\
(\mathrm{g} / \text { culture })\end{array}$ \\
\hline 4 & $52.21 \pm 2.78 \mathrm{c}$ & $8.25 \pm 2.03 \mathrm{bc}$ & $0.98 \pm 0.13 \mathrm{~b}$ & $0.07 \pm 0.01 \mathrm{a}$ \\
5 & $70.66 \pm 1.503 \mathrm{~b}$ & $10.05 \pm 2.07 \mathrm{~b}$ & $1.19 \pm 0.11 \mathrm{ab}$ & $0.18 \pm 0.08 \mathrm{a}$ \\
5.8 & $84.63 \pm 2.04 \mathrm{a}$ & $21.04 \pm 2.77 \mathrm{a}$ & $2.50 \pm 0.29 \mathrm{a}$ & $0.24 \pm 0.07 \mathrm{a}$ \\
7 & $47.49 \pm 2.09 \mathrm{c}$ & $5.28 \pm 1.79 \mathrm{bc}$ & $0.82 \pm 0.35 \mathrm{~b}$ & $0.06 \pm 0.02 \mathrm{a}$ \\
8 & $22.04 \pm 2.65 \mathrm{~d}$ & $1.81 \pm 1.06 \mathrm{c}$ & $0.45 \pm 0.26 \mathrm{~b}$ & $0.02 \pm 0.004 \mathrm{a}$ \\
\hline
\end{tabular}

*values are means \pm standard error of three replicates and different alphabets denotes significance at $\mathrm{P}<0.01$

\subsection{Adventitious root culture}

Biomass formation of the adventitious root culture in suspension culture of Brassica. olerace var. acephala showed a swift inclined in growth curve. This inclined was characterized by an initial lag phase of 7 days for fresh and dry weight, followed by log phase of 35 days and a subsequent stationary phase during 63 days period of culture (Fig 2). Maximum fresh weight (FW) and dry weight (DW) of $3.19 \pm 0.044$ and $0.338 \pm 0.006 \mathrm{~g} /$ culture, respectively, were observed on the 49th day of culture. A highest fresh weight (FW), 6-times than the initial inoculum weight $(0.5 \mathrm{~g})$ of ARs were attained in shake flask bioreactor. This increase in roots FW was also characterized by steady decrease in culture volume with time, and was linked with the nutrients and water ingestion by roots for growth and biomass accumulation.

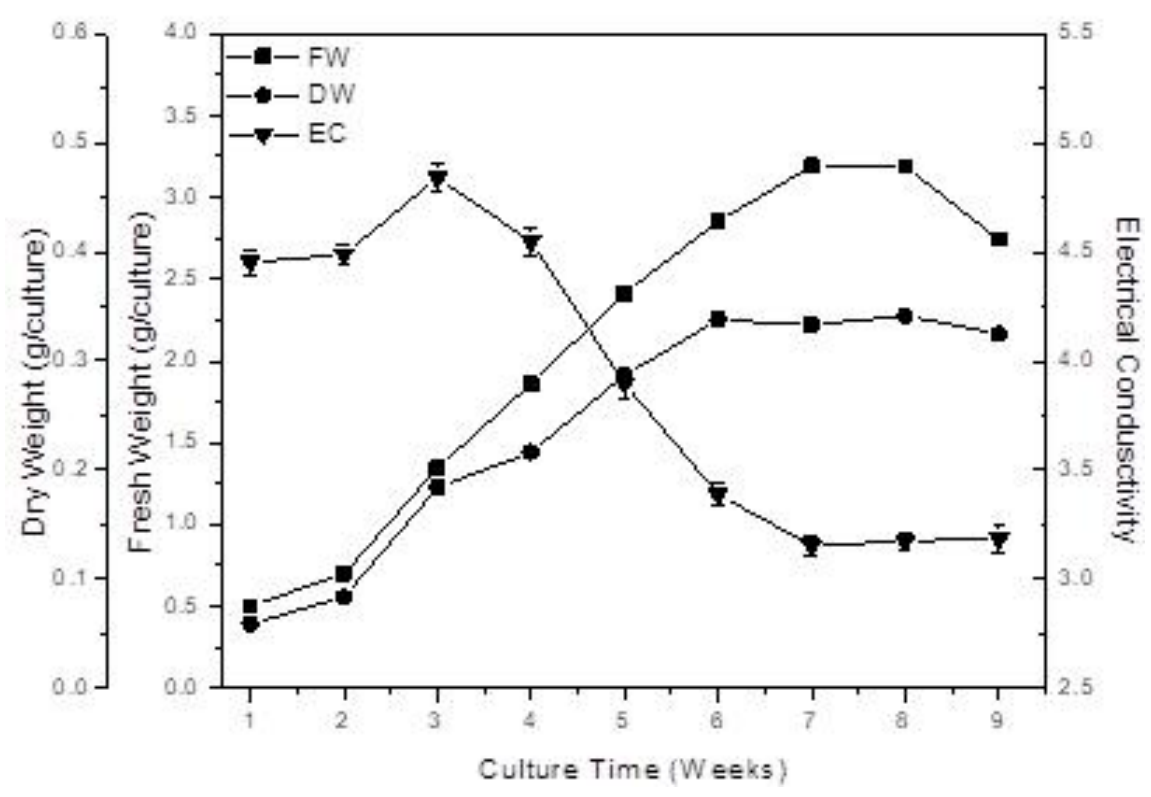

Figure 3. Total phenolic content (TPC) and total flavonoid content (TFC) with respect to dry weight (DW) accumulation.

The electrical conductivity (EC) of medium showed a gradual decline which can be linked with the nutrients consumption by the growing roots. This decrease was characterized by an initially increase and might be explained from an assumption that roots excrete metabolites for its adjustment to the new environment. The increase in biomass accumulation and decline in EC of exhausted MS media are associated with the nutrients uptake (PO4 ${ }^{-}, \mathrm{NH}^{+}, \mathrm{NO}^{-}$, etc.) from media by the ARs [24]. 
In the present study, the overall pattern of total phenolic content and total flavonoid content accumulation in adventitious root cultures displayed a growth-dependent pattern. TPC and TFC detected in 1 week old cultures were $3.39 \mathrm{mg} \mathrm{g}^{-1} \mathrm{DW}$ and $0.24 \mathrm{mg} \mathrm{g}^{-1} \mathrm{DW}$, respectively, that reached to its respective maximum values of $27.4 \mathrm{mg} \mathrm{g-1} \mathrm{DW} \mathrm{and} 8.8 \mathrm{mg} \mathrm{g}^{-}$ ${ }^{1}$ DW in 7-week-old cultures (Fig 3). The phenolic and flavonoid content in ARs were termed as gallic acid and quercetin equivalent, respectively based on the used standers (gallic acid and quercetin).

\subsection{Antioxidant activity}

Antioxidant activity of adventitious root cultures was determined by three different methods; DPPH radical scavenging assay, reducing power assay and total antioxidant capacity (Fig 4). These activities were estimated as ascorbic acid equivalent (AAE). Highest levels of DPPH radical scavenging activity $(73.1 \pm 5.9 \%)$, reducing power $(1.51 \pm 0.17 \mathrm{mg} \mathrm{AAE} / \mathrm{g} \mathrm{DW})$ and total antioxidant activity $(3.66 \pm 0.13 \mathrm{mg}$ AAE/g DW) were displayed by 7 -week old cultures (Fig 4).


Figure 4. Antioxidant activities of adventitious root cultures as radical scavenging activity (RSA), reducing power assay (RPA) and total antioxidant capacity (TAC), with respect to time of harvest. 


\section{DISCUSSION}

In the preliminary studies, internode and cotyledon explants were cultured for adventitious root induction. Among both the explants investigated, maximum $87 \%$ adventitious root formation was found in cotyledon explants; however internodes explants remained quiescent during the same culture conditions and minimum $34 \%$ rooting was observed. The morphological and physiological differences in these two explants explains the different rooting tendency at the same hormonal treatments [25]. By using cotyledon explants in the subsequent experiments, the adventitious root induction frequency was more pronounced with NAA compared to similar concentrations of IAA and IBA. These ARs in NAA containing MS medium were many in number, thick and white in appearance, and shorter in length without lateral branching. However, ARs in IAA supplemented media were few in number, profusely branched and slender in strength.

We found that sucrose concentration and $\mathrm{pH}$ level effected adventitious root induction significantly. MS medium augmented with $40 \mathrm{~g} \mathrm{~L}^{-1}$ of sucrose was supportive for maximum percent root induction while sucrose level higher than 40 significantly impaired the roots formation in cotyledon explants. As has been reported, sucrose act as building block of living cell [26] and adjust the cellular osmotic potential [27], the decrease in biomass accumulation at elevated sucrose concentration might be attributed to higher osmotic pressure that is deleterious to root primordia growth [28]. Similar observations were also made by Baque et al. [4] and Wang \& Weathers [28].

Medium $\mathrm{pH}$ is reported to effect the solubility of nutrient elements by changing their ionic forms [24]. The decrease in biomass accumulation at both extremes of $\mathrm{pH}$ (4.0 and 8.0) might be due to the availability of some nutrient elements, like trace elements at acidic $\mathrm{pH}$ are more available while calcium $(\mathrm{Ca})$ and phosphorous $(\mathrm{P})$ are less available [29].

Plants are the source of structurally diverse secondary metabolites which are grouped into several classes (phenols, alkaloids, saponins, etc) and among these polyphenols are considered as the largest class of organic antioxidants [30]. These phenolics antioxidants are safer then vitamin $\mathrm{C}$ and $\mathrm{E}$ supplements, and more potent to scavenge the reactive free radicals [31]. The present study reports the viable alternative for large scale production of antioxidants in ARs culture, which can be scaled up to bioreactor scale for commercial production. We found a positive correlation of phenolics and flavonoids with antioxidant activities in adventitious root cultures. Several studies attributed the antioxidant activity (DPPH, total antioxidant activity and reducing power) to phenolic content in plant samples [32,33], which have been proved to be more potent than synthetic antioxidants. Earlier authors [34, 35] have observed a direct correlation between antioxidant activity and reducing power of certain plant extracts. Previously, adventitious root cultures for other medicinal plants have been reported but this study reports ARs culture of Brassica oleracea var. acephala for the first time to produce phenolic and flavonoids using shack flask bioreactor [4, 27, 36, 37]. The fast growth rate of ARs in this study also opens the gate to genetic engineers for recombinant therapeutic proteins production.

\section{CONCLUSION}

The present study showed growth-associated increase in total phenolic content and total flavonoid content, which were found in a linear correlation with antioxidant activities. Additionally, this protocol can be exploited for production of other medicinally valuable secondary metabolites including glucosinolates and brassinosteroids. 


\section{Acknowledgements}

We do acknowledge the Quaid I Azam University Islamabad, Pakistan for providing the resources and consumables to conclude this work. Also we extand ours thanks to the Higher Education Comision (HEC), Pakistan for facilitating the research culture and promoting the higher education in the country.

\section{ORCID}

\section{Muhammad Adil (iD http://orcid.org/0000-0001-7328-1550 \\ Bilal Haider Abbasi (iD https://orcid.org/0000-0001-5245-6294}

\section{REFERENCES}

[1]. Carvalho, E.B. \& Curtis, W.R. (1998). Characterization of fluid-flow resistance in root cultures with a convective flow tubular bioreactor. Biotechnology and Bioengineering, 60 , 375-384.

[2]. Nagarajan, A., Arivalagan, U. \& Rajaguru, P. (2011). In vitro root induction and studies on antibacterial activity of root extract of Costus igneus on clinically important human pathogens. J ournal of Microbiology and Biotechnology Research, 1, 67-76.

[3]. Cui., X.H., Chakrabarty, D., Lee E.J. \& Paek, K.Y. (2010a). Production of adventitious roots and secondary metabolites by $\mathrm{H}$ ypericum perforatum L. in a bioreactor. Bioresource Technology, 101, 4708-4716.

[4]. Baque, M.A., Elgirban, A., Lee, E.J. \& Paek, K.Y. (2012). Sucrose regulated enhanced induction of anthraquinone, phenolics, flavonoids biosynthesis and activities of antioxidant enzymes in adventitious root suspension cultures of Morinda citrifolia (L.). Acta physiologia Plantarum, 34, 405-415.

[5]. Cogbill, S., Faulcon, T., Jones, G., McDaniel, M., Harmon, G., Blackmon, R. \& Young, M. (2010). Adventitious shoot regeneration from cotyledonary explants of rapid-cycling fast plants of Brassica rapa L. Plant cell Tissue O rgan, 101, 127-133.

[6]. Musgrave, M.E. (2000) Realizing the potential of rapid-cycling Brassica as a model system for use in plant biology research. J ournal of Plant G rowth Regulation, 19, 314-325.

[7]. BALC U, S.L., Apahidean, M., Zaharia, A. \& Delia, P. (2012). The Influence of Organic Fertilizers Concerning the Growth and Development of Brassica oleracea var. acephala Plants. Bulletin of University of Agricultural Sciences and Veterinary Medicine ClujNapoca Horticulture, 69 (1), 64-70.

[8]. Balkaya, A. \& Yanmaz, R. (2005) Promising kale (Brassica oleracea var. acephala) populations from Black Sea region, Turkey. New Zealand J ournal of Crop Horticulture, $33,1-7$.

[9]. Indrea, D., Apahidean, S., Apahidean, M., Măniuțiu, D. \& Sima, R. (2009). Vegetable F arming, Ed. Ceres, București

[10]. Nieuwhof, M. (1969). Cole Crops. Leonard Hill. Cole Crops Leonard Hill

[11]. Moreno, D.A., Carvajal, M., López-Berenguer, C. \& García-Viguera, C. (2006) Chemical and biological characterisation of nutraceutical compounds of broccoli. Journal of Pharmaceutical and Biomedical analysis, 41, 1508-1522.

[12]. Traka, M. \& Mithen, R. (2009). Glucosinolates, isothiocyanates and human health. Phytochemistry Review, 8, 269-282.

[13]. Patel, D., Prasad, S. Kumar, R. \& Hemalatha, S. (2012). An overview on antidiabetic medicinal plants having insulin mimetic property. Asian Pacific Journal of Tropical Biomedicine, 2, 320-330.

[14]. Roman-Ramos, R., Flores-Saenz, J. \& Alarcon-Aguilar, F. (1995). Anti-hyperglycemic effect of some edible plants. J ournal of Ethnopharmacology, 48, 25-32. 
[15]. Pinheiro, C. \& Chaves, M. (2011). Photosynthesis and drought: can we make metabolic connections from available data? Journal of Experimental Botany, 62, 869-882.

[16]. Hutchinson, J.F. (1995). F undamentals of plant propagation by tissue culture [electronic resource] / J.F. Hutchinson and M. Barlass. Agriculture notes (Victoria. Dept. of Primary Industries) ; AG0245, vol Accessed from http://nla.gov.au/nla.cat-vn4224643 Dept. of Primary Industries, [Knoxfield, Vic.]

[17]. Murashige, T. \& Skoog, F. (1962). A revised medium for rapid growth and bio assays with tobacco tissue cultures. Physiologia Plantarum., 15, 473-497.

[18]. Baque, M.A., Hahn, E.J. \& Paek, K.Y. (2010). Growth, secondary metabolite production and antioxidant enzyme response of Morinda citrifolia adventitious root as affected by auxin and cytokinin. Plant Biotechnology Report, 4, 109-116.

[19]. Tariq, U., Ali, M. \& Abbasi, B.H. (2014). Morphogenic and biochemical variations under different spectral lights in callus cultures of Artemisia absinthium L. Journal of Photochemistry \& Photobiology B, 130, 264-271.

[20]. Ali, M. \& Abbasi, B.H. (2013). Production of commercially important secondary metabolites and antioxidant activity in cell suspension cultures of Artemisia absinthium L. Industrial Crops Produdcts, 49, 400-406.

[21]. Abbasi, B.H., Khan, M.A., Mahmood, T., Ahmad, M., \& Chaudhary M.F. (2010). Shoot regeneration and free-radical scavenging activity in Silybum marianum L. Plant Cell Tissue and Organ. Culture, 101, 371-376.

[22]. Prieto, P., Pineda, M. \& Aguilar M. (1999). Spectrophotometric quantitation of antioxidant capacity through the formation of a phosphomolybdenum complex: specific application to the determination of vitamin E. Analytical Biochemistry, 269, 337-341.

[23]. Dorman, H., Peltoketo, A., Hiltunen, R. \& Tikkanen, M. (2003). Characterisation of the antioxidant properties of de-odourised aqueous extracts from selected Lamiaceae herbs. F ood Chemistry, 83, 255-262.

[24]. Liu, C.Z., Abbasi, B.H., Gao, M., Murch, S.J. \& Saxena, P.K. (2006). Caffeic acid derivatives production by hairy root cultures of Echinacea purpurea. Journal of Agriculture and F ood Chemistry, 54, 8456-8460.

[25]. Zhu, XY., Chai, SJ., Chen, L.P., Zhang, M.F. \& Yu, J.Q. (2010). Induction and origin of adventitious roots from chimeras of Brassica juncea and Brassica oleracea. Plant Cell Tissue and Organ Culture, 101, 287-294.

[26]. Calamar, A. \& De Klerk, G.J. (2002). Effect of sucrose on adventitious root regeneration in apple. Plant Cell Tissue and Organ Culture, 70, 207-212.

[27]. Cui., X.H., Murthy, H., Wu, C.H. \& Paek, K.Y. (2010b). Sucrose-induced osmotic stress affects biomass, metabolite, and antioxidant levels in root suspension cultures of H ypericum perforatum L. Plant cell Tissue and Organ Culture, 103, 7-14.

[28]. Wang, Y. \& Weathers, P. (2007). Sugars proportionately affect artemisinin production. Plant Cell Reports, 26, 1073-1081.

[29]. Abbasi, B.H., C.L. Tian, Murch, S.J., Saxena P.K. \& Liu., C.Z. (2007). Light-enhanced caffeic acid derivatives biosynthesis in hairy root cultures of Echinacea purpurea. Plant Cell Report, 26, 1367-1372.

[30]. Cieśla, Ł., Kowalska, I., Oleszek, W. \& Stochmal, A. (2013). Free Radical Scavenging Activities of Polyphenolic Compounds Isolated from Medicago sativa and Medicago truncatula Assessed by Means of Thin-layer Chromatography DPPH' Rapid Test. Phytochemical Analysis, 24, 47-52.

[31]. Rice-Evans, C.A., Miller, N.J. \& Paganga, G. (1996). Structure-antioxidant activity relationships of flavonoids and phenolic acids. Free Radical Biology and M edicine, 20, 933-956. 
[32]. Li, S.W., Xue, L., Xu, S., Feng H. \& An, L. (2009). Mediators, genes and signaling in adventitious rooting. The Botanical Review, 75, 230-247.

[33]. Ferreres, F., Fernandes, F., Sousa, C., Valentão, P.C., Pereira, J.A. \& Andrade, P.B. (2009). Metabolic and bioactivity insights into Brassica oleracea var. acephala. J ournal of Agriculture and F ood Chemistry, 57, 8884-8892.

[34]. Velioglu, Y., Mazza, G., Gao, L. \& Oomah, B. (1998). Antioxidant activity and total phenolics in selected fruits, vegetables, and grain products. J ournal of Agriculture and F ood Chemistry, 46, 4113-4117.

[35]. Gil, M.I., Tomás-Barberán, F.A., Hess-Pierce, B., Holcroft, D.M. \& Kader, A.A. (2000). Antioxidant activity of pomegranate juice and its relationship with phenolic composition and processing. J ournal of Agriculture and F ood Chemistry, 48 (10):4581-4589.

[36]. Lee, E.J. \& Paek, K.Y. (2012). Enhanced productivity of biomass and bioactive compounds through bioreactor cultures of Eleutherococcus koreanum Nakai adventitious roots affected by medium salt strength. Industrial Crops and P roducts, 36, 460-465.

[37]. Wu, C.H., Murthy, H.N., Hahn E.J. \& Paek, K.Y. (2008). Establishment of adventitious root co-culture of Ginseng and Echinacea for the production of secondary metabolites. Acta P hysiologiae Plantarum, 30, 891-896. 